\section{Arrkivoc

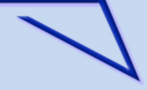

Archive for

Organic Chemistry
The Free Internet Journal

for Organic Chemistry
Paper

Arkivoc 2018, part iii, 134-143

\title{
Highly diastereoselective synthesis of a novel functionalized triepoxytrinaphthylene
}

\author{
Musa Erdoğan, ${ }^{a}$ Selçuk Eşsiz, ${ }^{a}$ Fabrizio Fabris, ${ }^{b}$ and Arif Daştan*,a \\ ${ }^{a}$ Department of Chemistry, Ataturk University, Faculty of Sciences, Erzurum, Turkey \\ ${ }^{b}$ Dipartimento di Scienze Molecolari e Nanosistemi, Università Ca' Foscari di Venezia, Venezia, Italy \\ E-mail: adastan@atauni.edu.tr
}

Dedicated to emeritus Professors Metin Balci (Middle East Technical University) and Ottorino De Lucchi (Ca Foscari University) for their valuable contribution to hydrocarbon chemistry.

Received 11-25-2017

Accepted 01-06-2018

Published on line 01-28-2018

\section{Abstract}

The high yielding synthesis of a novel benzocyclotrimer is herein presented. The syn-diastereomer is obtained as major product, presumably in virtue of the presence of an oxa-bridge of the bicylic components. The three oxa-bridges can be used for further functionalization, as well as the six bromine atoms of the three aromatic rings, as demonstrated in the aromatization of a mixture of anti-1 and syn-1 (3:7) leading to trinaphthylene.
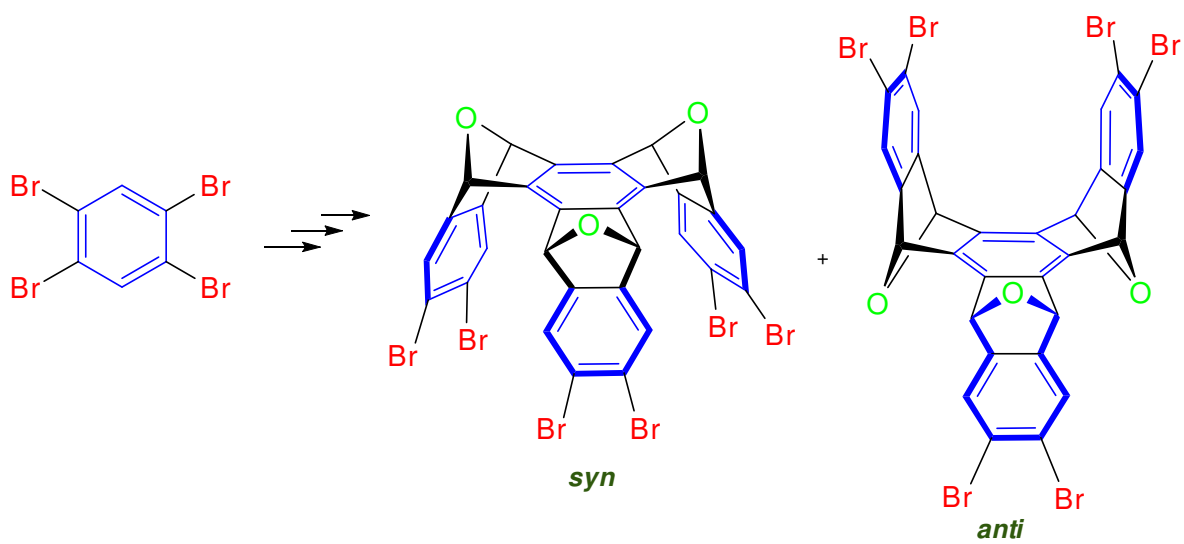

Keywords: Cyclotrimerization, copper, cup-shaped molecules, stereoselective reactions, aromatic compounds Introduction 
Benzocyclotrimers ${ }^{1}$ are rigid molecules characterized by one or two cavities, which have been successfully employed in supramolecular chemistry. ${ }^{2-15}$ Amongst these, benzocyclotrimers bearing aromatic rings are characterized by large stiff cavities. The cavities are particularly deep and suitable for supramolecular applications in case of the more symmetrical syn-diastereomer, which is generally obtained in lower yields. In this report we describe the highly diastereoselective synthesis of the benzocyclotrimer syn-1, displaying one rigid and functionalized hemi-cavity in the bottom of the structure, concomitantly with three relatively reactive oxa-bridges (Figure 1). The reactivity of these moieties can be conveniently used for further functionalization of the less valuable diastereomer anti-1, which furnished the more symmetrical trinaphtylene $\mathbf{2}$ (Figure 1).

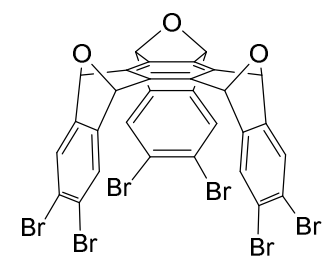

syn-1

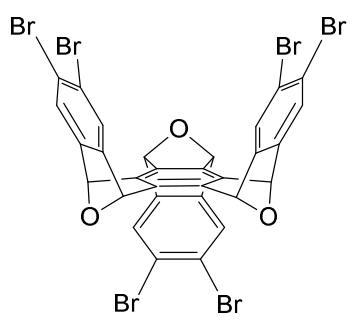

anti-1

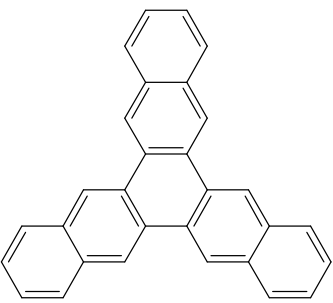

2

Figure 1. $\mathrm{C}_{3 \mathrm{v}^{-}}$and $\mathrm{C}_{\mathrm{S}^{-}}$symmetric benzocyclotrimer syn-1 and anti-1, and trinaphtylene 2.

\section{Results and Discussion}

The starting material for the synthesis of the benzocyclotrimers syn-1 and anti-1 was 4,5-dibromo-11oxatricyclo[6.2.1.0 $0^{2,7}$ undeca-2(7),3,5,9-tetraene 4, which can be obtained in $85 \%$ overall yield from commercially available 1,2,4,5-tetrabromobenzene 3 . The latter reacted with $n$-butyl lithium to afford 1 lithium-2,4,5-tribromobenzene, which decomposes to form the 4,5-dibromobenzyne. This reactive intermediate was captured by furan, acting as dienophile in a [4+2] cycloaddition (Scheme 1). ${ }^{16-25}$ The resulting oxabicycle 4 was brominated according to a well-established radical-driven procedure, ${ }^{14}$ which avoids Meerwein rearrangement with concomitant opening of the oxa-bridge (Scheme 1). ${ }^{26}$ The radical bromination of 4 with 1,2-dibromotetrachloroethane (DBTCE) furnished the trans-dibromide diastereomer $\mathbf{5}$ in high yields (85\%) (Scheme 1). In order to obtain the alkenyl bromide 6 the dehydrobromination reaction with potassium tert-butoxide in THF was used, ${ }^{26}$ to afford the desired product 6 in good yield (90\%) (Scheme 1). The latter was brominated under high temperature conditions, which ensures high yields of dibromination, with limited amounts of Meerwein rearrangement products, ${ }^{26}$ to obtain alkenyl tribromides exo-7 and endo-7, in a ratio of 2:1 and $96 \%$ overall yield (Scheme 1). The mixture of diastereomers was dehydrobrominated with potassium tert-butoxide in $\mathrm{THF}^{26}$ to afford the alkenyldibromide 8 in good yield (93\%) (Scheme 1). 


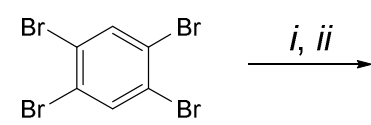

3

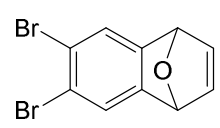

4
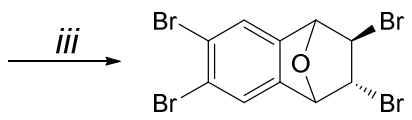

5

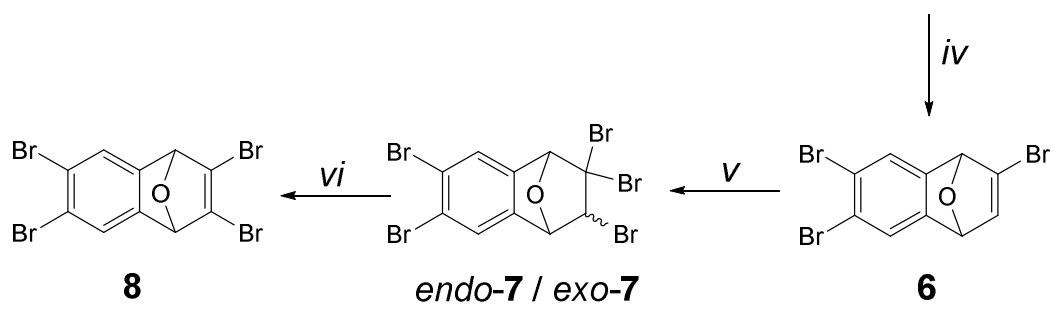

Scheme 1. Synthesis of the key intermediates for the precursor of the cyclotrimerization. (i) $n$-BuLi; (ii) furan in toluene, $-78{ }^{\circ} \mathrm{C}$ to rt (85\% for two steps) (iii) DBTCE, in $\mathrm{CCl}_{4}, \mathrm{hv},(85 \%)$, (iv) $t$-BuOK in THF, reflux. (90\%) $\left.v\right) \mathrm{Br}_{2}$ in $\mathrm{CCl}_{4}$, reflux. (96\%) (vi) $t$-BuOK in THF, reflux (93\%).

The key reagent 9 for the cyclotrimerization was obtained either by proton abstraction of halide 6 with lithium diisopropylamide (LDA) ${ }^{11,13,27-33}$ or by removal of one of the bromine atoms of the dibromide 8 with $n$ butyl lithium ${ }^{30,31,34,35}$ followed by a trans-metalation reaction with trimethyltin chloride in $96 \%$ yield in both cases. The high chemoselectivity of removal of the bromine atom in $\mathbf{8}$ was surprisingly: indeed, the bromine atoms attached to the aromatic ring remained completely unaffected.

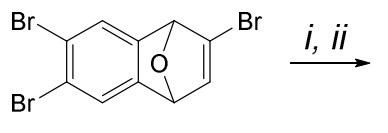

6

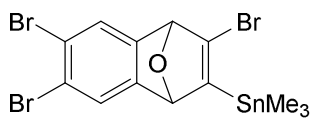

9
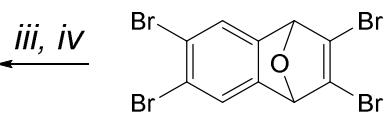

8

Scheme 2. Two feasible strategies the preparation of the precursor of cyclotrimerization 9. (i) $\mathrm{LDA}$ (ii) $\mathrm{Me}{ }_{3} \mathrm{SnCl}$ in THF, $-78^{\circ} \mathrm{C}$ to rt, ( $96 \%$ for two steps). (iii) $n$-BuLi; (iv) $\mathrm{Me}_{3} \mathrm{SnCl}$ in THF, $-78^{\circ} \mathrm{C}$ to rt, ( $96 \%$ for two steps).

In order to accomplish the cyclotrimerization, the vic-bromostannane 9 was treated with copper(I) 2thiophenecarboxylate (CUTC) in dry NMP ( $N$-methyl-2-pyrrolidone) at low temperature. ${ }^{36}$ The two isomeric benzocyclotrimers were formed in a highly favourable 7:3 syn to anti ratio and in a very good isolated yield (92\%). The selectivity was opposite to the expected statistical distribution observed in the majority of cyclotrimerization reactions. ${ }^{1}$ This behaviour has been previously observed when a ligating group is present in the monomer. ${ }^{37,38,11,32}$ It is likely that the oxa-bridge in the dihydronaphthalene is responsible for the high reverse selectivity, by means of coordination with copper. The separation of the two isomers was easily accomplished by chromatography on neutral alumina and the major syn-1 isomer was available for further functionalization and supramolecular studies. 


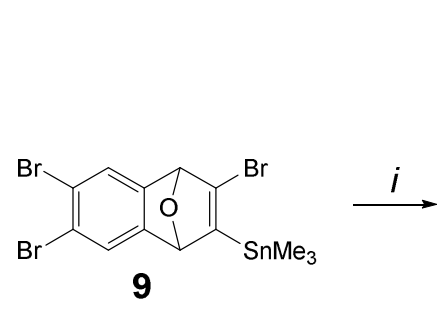

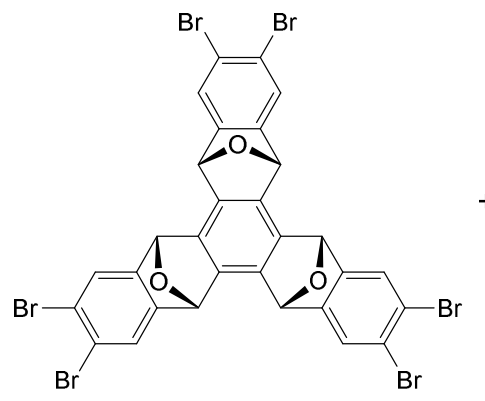

syn-1

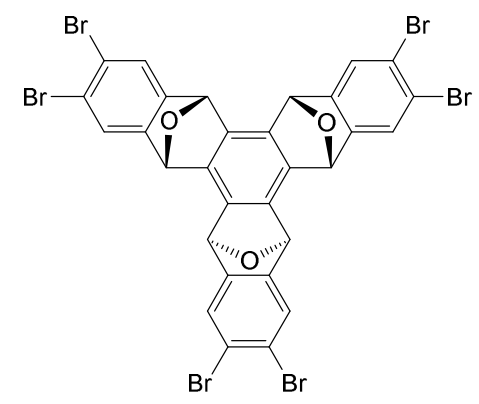

anti-1

Scheme 3. Copper-mediated cyclotrimerization of 9. (i) CuTC in NMP, $-20{ }^{\circ} \mathrm{C}$ ( $25 \%$ for anti-1 and $67 \%$ syn-1 isolated yield).

The cyclotrimers syn-1 and anti-1 are a potential source for the synthesis of polyaromatic rings. In order to verify the potential of this strategy a mixture of syn-1 and anti-1 have been submitted to reductive oxygen elimination reactions. ${ }^{39-42}$ The milder methodologies ${ }^{39-41}$ based on the use of trimethylsilyl iodide or low valent titanium(III)chloride furnished complex mixtures of products, containing minor amounts of the expected 2,3,8,9,14,15-hexabromotrinaphthylene. When pure syn-1 or anti-1 (or mixture of syn-1 and anti-1) is treated with titanium(III)chloride, generated in situ from $\mathrm{TiCl}_{4}$, lithium aluminum hydride (LAH) and triethylamine (TEA) in refluxing THF, ${ }^{42}$ a quantitative yield of trinaphthylene $2^{43-50}$ is obtained.

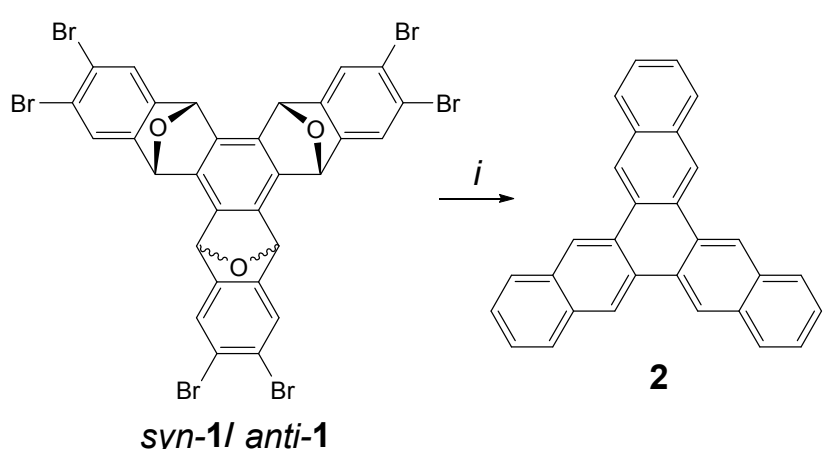

Scheme 4. Reductive aromatization of benzocyclotrimer syn-1 and anti-1. (i) $\mathrm{TiCl}_{4}, \mathrm{LAH}, \mathrm{TEA}$ in THF, reflux (100\% yield).

This approach opens up a new possible method for the preparation of polyaromatic systems, based on the highly chemo- and stereoselective cyclotrimerization reaction. ${ }^{51}$

\section{Conclusions}

In conclusion, a straightforward and high yielding synthesis of a new benzocyclotrimer was developed. The cyclotrimerization reaction afforded two possible diastereomers syn to anti in a very favourable 7:3 ratio. The more valuable syn-diastereomer will be considered for supramolecular applications. On the other hand, anti and syn diastereomers may be conveniently employed for the preparation of polyaromatic structures. 


\section{Experimental Section}

General. All reactions were carried out under nitrogen and monitored by TLC and/or ${ }^{1} \mathrm{H}-\mathrm{NMR}$ spectroscopy. All solvents were dried and distilled before use. Column chromatography was performed on silica gel (60 mesh, Merck) or on neutral alumina. TLC was carried out on silica gel 60 HF254 aluminum plates (Fluka). Melting points are uncorrected. The ${ }^{1} \mathrm{H}$ - and ${ }^{13} \mathrm{C}$-NMR spectra were recorded on $400 \mathrm{MHz} N M R$ spectrometers. Apparent splittings are given in all cases in ppm and coupling constants $J$ in $\mathrm{Hz}$. All new compounds gave satisfactory elemental analyses and/or HRMS (Q-TOF). All substances reported in this paper are in their racemic form.

4,5-Dibromo-11-oxatricyclo[6.2.1.0 $\left.{ }^{2},{ }^{7}\right]$ undeca-2(7),3,5,9-tetraene (4). To a mixture of 1,2,4,5tetrabromobenzene $3(5.00 \mathrm{~g}, 12.70 \mathrm{mmol})$ and furan $(10 \mathrm{~mL}, 138.40 \mathrm{mmol})$ in toluene $(100 \mathrm{~mL})$ was added $n$ BuLi $(2.5 \mathrm{M}$ in $n$-hexane, $5.6 \mathrm{ml}, 13.97 \mathrm{mmol})$ at $-78^{\circ} \mathrm{C}$. The resulting mixture was stirred for $1 \mathrm{~h}$. The resulting reaction mixture was allowed to warm up to room temperature and stirred overnight. The mixture was diluted with saturated solution of ammonium chloride $(10 \mathrm{ml})$ and extracted with EtOAc $(3 \times 25 \mathrm{~mL})$. Combined organic layers were washed with brine, dried over $\mathrm{Na}_{2} \mathrm{SO}_{4}$ and concentrated. The residue was purified via column chromatography (silica-gel, $100 \mathrm{~g}$; eluant 1:9 EtOAc/n-hexane) to obtain 6,7-dibromo-1,4-dihydro-1,4epoxynaphthalene 4 (3.26 g, 85\%) as colourless crystals from $\mathrm{CH}_{2} \mathrm{Cl}_{2} / n$-hexane (1:9), M.p. $125-126{ }^{\circ} \mathrm{C}$ (lit. ${ }^{19}$ M.p. $\left.125.2-126.6{ }^{\circ} \mathrm{C}\right) .{ }^{1} \mathrm{H}$ NMR $\left(400 \mathrm{MHz}, \mathrm{CDCl}_{3}\right): 7.47$ (s, $\left.2 \mathrm{H}\right), 6.99$ (s, $\left.2 \mathrm{H}\right), 5.65$ (s, $\left.2 \mathrm{H}\right) .{ }^{13} \mathrm{C} \mathrm{NMR}(100 \mathrm{MHz}$, $\left.\mathrm{CDCl}_{3}\right): 150.2,142.7,125.5,120.6,81.8$.

trans-4,5,9,10-Tetrabromo-11-oxatricyclo[6.2.1.02, 7 undeca-2(7),3,5-triene (5). In a 100-mL flask equipped with a reflux condenser, a solution of 4 (3.00 g, $9.93 \mathrm{mmol}), 3.88 \mathrm{~g}$ (11.92 mmol) of DBTCE, and AIBN (10 mg) in $\mathrm{CCl}_{4}(40 \mathrm{~mL})$ was irradiated with a $500 \mathrm{~W}$ halogen lamp while refluxing for $24 \mathrm{~h}$. Volatile materials were removed at reduced pressure and the residue was purified via column chromatography (silica-gel, $100 \mathrm{~g}$; eluant $n$-hexane) to afford trans-2,3,6,7-tetrabromo-1,2,3,4-tetrahydro-1,4-epoxynaphthalene 5 (3.90 g, 85\%) as colorless crystals from $\mathrm{CH}_{2} \mathrm{Cl}_{2} / n$-hexane (1:9), M.p. 112-114 ${ }^{\circ} \mathrm{C}$. IR ( $\left.\mathrm{KBr}\right): 3003,1603,1566,1440,1359$, 1319, 1217, 1192, 1088, 983. ${ }^{1} \mathrm{H}$ NMR (400 MHz, CDCl $)$ : 7.64 (s, $\left.1 \mathrm{H}\right), 7.62$ (s, $\left.1 \mathrm{H}\right), 5.39$ (bs, $\left.1 \mathrm{H}\right), 5.38$ (d, J = 4.8, $1 \mathrm{H}), 4.49(\mathrm{dd}, J=4.8$ and 2.6, $1 \mathrm{H}), 3.77(\mathrm{~d}, J=2.6,1 \mathrm{H}) \cdot{ }^{13} \mathrm{C} \mathrm{NMR}\left(100 \mathrm{MHz}, \mathrm{CDCl}_{3}\right): 142.4$ (2 overlapping C), $128.5,125.3,124.5,124.1,86.4,82.7,51.9,49.8$. Anal. calc. for $\mathrm{C}_{10} \mathrm{H}_{6} \mathrm{Br}_{4} \mathrm{O}$ : C 26.01, $\mathrm{H} 1.31$; found: $\mathrm{C} 26.07$, H 1.33 .

4,5,9-Tribromo-11-oxatricyclo[6.2.1.0 ${ }^{2}, 7$ ] undeca-2(7),3,5,9-tetraene (6). Under $\mathrm{N}_{2}$ atmosphere, a solution of potassium tert-butoxide $(0.58 \mathrm{~g}, 5.20 \mathrm{mmol})$ in dry THF $(10 \mathrm{~mL})$ was added to a stirred solution of $5(2.00 \mathrm{~g}$, $4.33 \mathrm{mmol})$ in dry THF $(20 \mathrm{~mL})$ in $15 \mathrm{~min}$. The resulting mixture was heated at reflux temperature for $3 \mathrm{~h}$. Volatile materials were evaporated and the residue was diluted with water and extracted with $\mathrm{Et}_{2} \mathrm{O}(3 \times 50$ $\mathrm{mL}$ ). Combined organic extracts were washed with water, dried over $\mathrm{MgSO}_{4}$, and concentrated at the reduced pressure. The residue was purified by column chromatography (silica-gel, 10 g; eluant EtOAc/ $n$-hexane (1:10)) to furnish 2,6,7-tribromo-1,4-dihydro-1,4-epoxynaphthalene 6 (1.50 g, 90\%) as light brown crystals from $\mathrm{CH}_{2} \mathrm{Cl}_{2} / n$-hexane (1:3), M.p. $115-116{ }^{\circ} \mathrm{C} . \mathrm{IR}(\mathrm{KBr}): 3014,1573,1431,1349,1318,1228,1152,1084,992 .{ }^{1} \mathrm{H}$ NMR (400 MHz, $\left.\mathrm{CDCl}_{3}\right): 7.60(\mathrm{~s}, 1 \mathrm{H}), 7.49(\mathrm{~s}, 1 \mathrm{H}), 6.92(\mathrm{~d}, \mathrm{~J}=2.0,1 \mathrm{H}), 5.69(\mathrm{~m}, 1 \mathrm{H}), 5.40(\mathrm{bs}, 1 \mathrm{H}) .{ }^{13} \mathrm{C} \mathrm{NMR}$ $\left(100 \mathrm{MHz}, \mathrm{CDCl}_{3}\right):$ 148.6, 148.1, 139.3, 136.3, 126.1, 125.4, 121.8, 121.1, 86.4, 83.8.

exo/endo-4,5,9,9,10-Pentabromo-11-oxatricyclo[6.2.1.0 $\left.{ }^{2},{ }^{7}\right]$ undeca-2(7),3,5-triene (exo/endo-7). $A$ hot solution of bromine $(0.23 \mathrm{~g}, 1.44 \mathrm{mmol})$ in $\mathrm{CCl}_{4}(5 \mathrm{~mL})$ was added dropwise to a magnetically stirred refluxing solution of tribromide $6(0.50 \mathrm{~g}, 1.31 \mathrm{mmol})$ in $\mathrm{CCl}_{4}(25 \mathrm{ml})$. The solution was maintained under reflux for 20 $\mathrm{min}$, after cooling to the room temperature the solvent was removed at the reduced pressure to afford a 2:1 
mixture of pentabromides exo-7 and endo-7 (0.68 $\mathrm{g}, 96 \%$ yield), which was used in the following transformation without further purification. ${ }^{1} \mathrm{H} \mathrm{NMR}\left(400 \mathrm{MHz}, \mathrm{CDCl}_{3}\right)$ of exo-7: $7.76(\mathrm{~s}, 1 \mathrm{H}), 7.62(\mathrm{~s}, 1 \mathrm{H}), 5.67$ $(\mathrm{s}, 1 \mathrm{H}), 5.38(\mathrm{~s}, 1 \mathrm{H}), 4.36(\mathrm{~s}, 1 \mathrm{H}) .{ }^{1} \mathrm{H}$ NMR $\left(400 \mathrm{MHz}, \mathrm{CDCl}_{3}\right)$ of endo-7: $7.69(\mathrm{~s}, 1 \mathrm{H}), 7.59(\mathrm{~s}, 1 \mathrm{H}), 5.67(\mathrm{~s}, 1 \mathrm{H})$, $5.43(\mathrm{~d}, J=4.7,1 \mathrm{H}), 5.11(\mathrm{~d}, J=4.7,1 \mathrm{H})$.

4,5,9,10-Tetrabromo-11-oxatricyclo[6.2.1.02, ] undeca-2(7),3,5,9-tetraene (8). Under $\mathrm{N}_{2}$ atmosphere, a solution of potassium tert-butoxide $(0.18 \mathrm{~g}, 1.55 \mathrm{mmol})$ in dry THF $(5 \mathrm{~mL})$ was added to a stirred solution of exo-7 and endo-7 $(0.70 \mathrm{~g}, 1.29 \mathrm{mmol})$ in dry THF $(20 \mathrm{~mL})$ in $15 \mathrm{~min}$. The resulting mixture was maintained at room temperature overnight. Volatile materials were evaporated and the residue was diluted with water and extracted with $\mathrm{Et}_{2} \mathrm{O}(3 \times 50 \mathrm{ml})$. Combined organic extracts were washed with water, dried over $\mathrm{MgSO}_{4}$ and concentrated at reduced pressure. The residue was purified by column chromatography (silica-gel, 20 g; eluant EtOAc/n-hexane (1:9)) to furnish 2,3,6,7-tetrabromo-1,4-dihydro-1,4-epoxynaphthalene 8 (0.55 g, 93\%) as colourless crystals from $\mathrm{CH}_{2} \mathrm{Cl}_{2} / n$-hexane (1:3), M.p. 197-199 ${ }^{\circ} \mathrm{C} . \mathrm{IR}(\mathrm{KBr}): 3014,1587,1429,1345,1317,1222$, 1155, 1082, 1053, 990. ${ }^{1} \mathrm{H}$ NMR (400 MHz, CDCl $): 7.60$ (s, $\left.2 \mathrm{H}\right), 5.52$ (s, $\left.2 \mathrm{H}\right) .{ }^{13} \mathrm{C} \mathrm{NMR}\left(100 \mathrm{MHz} \mathrm{CDCl}_{3}\right): 146.8$, 133.3, 125.9, 122.2, 87.5. Anal. calc. for $\mathrm{C}_{10} \mathrm{H}_{4} \mathrm{Br}_{4} \mathrm{O}$ : C 26.12, $\mathrm{H}$ 0.88; found: C 26.13, H 0.93.

4,5,9-Tribromo-10-(trimethylstannyl)-11-oxatricyclo[6.2.1.0 ${ }^{2}$, ]undeca-2(7),3,5,9-tetraene (9). Method A. Under $\mathrm{N}_{2}$, A solution of $n$-BuLi in $n$-hexane $(2.5 \mathrm{~m}, 0.05 \mathrm{ml}, 1.25 \mathrm{mmol})$ was added dropwise to a solution of tetrabromide $8(0.55 \mathrm{~g}, 1.19 \mathrm{mmol})$ in dry THF $(20 \mathrm{~mL})$ at $-78{ }^{\circ} \mathrm{C}$ and the resulting mixture was stirred at the same temperature for $1 \mathrm{~h}$. Trimethyltin chloride $(0.22 \mathrm{~g}, 1.43 \mathrm{mmol})$ was added to the reaction mixture in one portion and the mixture was stirred $2 \mathrm{~h}$ at the same temperature. The resulting mixture was allowed to warm to room temperature overnight, it was diluted with water $(50 \mathrm{~mL})$ and extracted with $\mathrm{Et}_{2} \mathrm{O}(3 \times 30 \mathrm{~mL})$. Combined ethereal extracts were dried over $\mathrm{MgSO}_{4}$, and concentrated in vacuo to afford the bromo-stannyl olefin 9, as a brown oil (0.68 g, 96\%).

Method B. Under $\mathrm{N}_{2}$ atmosphere, a solution of $n$-BuLi in hexane $(2.5 \mathrm{M}, 1.3 \mathrm{~mL}, 2.63 \mathrm{mmol})$ was added to a solution of dry diisopropylamine $(0.40 \mathrm{~mL}, 2.88 \mathrm{mmol})$ in dry THF $(5 \mathrm{~mL})$ cooled at $-78{ }^{\circ} \mathrm{C}$. After $15 \mathrm{~min}$, a solution of $6(0.50 \mathrm{~g}, 1.31 \mathrm{mmol})$ in dry THF $(15 \mathrm{ml})$ was added and the mixture was maintained at the same temperature for $1 \mathrm{~h}$. A solution of trimethyltin chloride $(0.31 \mathrm{~g}, 1.58 \mathrm{mmol})$ in dry THF (10 $\mathrm{mL}) \mathrm{was}$ added dropwise and the temp. was left to rise to r.t. overnight. The final mixture was diluted with water $(50 \mathrm{~mL})$ and extracted with $\mathrm{Et}_{2} \mathrm{O}(3 \times 50 \mathrm{~mL})$. Combined ethereal extracts were dried over $\mathrm{Na}_{2} \mathrm{SO}_{4}$, and concentrated in vacuo to afford the bromo-stannyl olefin 9, as a brown oil $(0.68 \mathrm{~g}, 96 \%) .{ }^{1} \mathrm{H} \mathrm{NMR}\left(400 \mathrm{MHz}, \mathrm{CDCl}_{3}\right): 7.56(\mathrm{~s}, 1$ H), $7.38(\mathrm{~s}, 1 \mathrm{H}), 5.73(\mathrm{~s}, 1 \mathrm{H}), 5.36(\mathrm{~s}, 1 \mathrm{H}), 0.27$ (s, $9 \mathrm{H}) .{ }^{13} \mathrm{C} \mathrm{NMR}\left(100 \mathrm{MHz}, \mathrm{CDCl}_{3}\right):$ 151.7, 149.2, 148.4, 146.3, 125.8, 124.7, 121.6, 120.8, 88.7, 86.8, -9.3. Compound 9 resulted pure enough for the following transformation and the purification was not attempted, because of the poor stability of the vinylstannane moiety on silica-gel.

syn- and anti-7,8,17,18,27,28-Hexabromo-31,32,33-trioxadecacyclo[22.6.1 $1^{4,11} \cdot 1^{14,21} \cdot 0^{2,23} \cdot 0^{3,12} \cdot 0^{5,10} \cdot 0^{13,22}$. $0^{15,20} \cdot 0^{25,30}$ ]tritriaconta-2,5,7,9,12,15,17,19,22,25,27,29-dodecaene (syn-1) and (anti-1). In a flame dried 50$\mathrm{ml}$ two-necked round-bottomed flask fitted with a nitrogen inlet, copper(I) 2-thiophenecarboxylate (CuTC) $(0.13 \mathrm{~g}, 0.69 \mathrm{mmol})$ was introduced, purging with nitrogen and capping with a rubber septum. The reactor was cooled to $-20{ }^{\circ} \mathrm{C}$ and consecutively dry NMP $(15 \mathrm{~mL})$ and bromostannyl-olefin 9 (0.25 g, 0.46 mmol) were added via syringe. The reaction evolution was monitored by ${ }^{1} \mathrm{H}-\mathrm{NMR}$ spectroscopy. After 30 min, an aqueous $10 \% \mathrm{NH}_{3}$ solution $(20 \mathrm{ml}$ ) was added and the mixture was stirred until the brown solid disappeared. The mixture was extracted with diethyl ether $(3 \times 20 \mathrm{ml})$ and the combined ethereal extracts were dried over $\mathrm{MgSO}_{4}$. Volatile materials were removed in vacuo, and the residue was purified by column chromatography on neutral aluminum oxide with EtOAc/n-hexane (3:7) as eluant. 
First eluate: (anti-1) (34 mg, $25 \%$ yield), colorless crystals from $\mathrm{CH}_{2} \mathrm{Cl}_{2} / n$-hexane (1:3), M.p. $>350{ }^{\circ} \mathrm{C}$ (dec.). IR (KBr): 3008, 1725, 1566, 1435, 1352, 1308, 1264, 1230, 1188, 1158, 1085, 987, 936, 903, 837. ${ }^{1} \mathrm{H}$ NMR (400 $\left.\left.\mathrm{MHz}, \mathrm{DMSO}-d_{6}\right): 7.87(\mathrm{~s}, 2 \mathrm{H}), 7.84(\mathrm{~s}, 2 \mathrm{H}), 7.82(\mathrm{~s}, 2 \mathrm{H}), 6.44(\mathrm{~s}, 2 \mathrm{H}), 6.42(\mathrm{~s}, 2 \mathrm{H}), 6.40(\mathrm{~s}, 2 \mathrm{H})\right) .{ }^{13} \mathrm{C} \mathrm{NMR}(100$ $\mathrm{MHz}$, DMSO- $d_{6}$ ): 149.4, 149.3, 149.3, 137.0, 136.7, 136.4, 126.9 (2 overlapping C), 126.6, 121.9, 121.9, 121.8, 79.9, 79.7, 79.6. Anal. calc. for $\mathrm{C}_{30} \mathrm{H}_{12} \mathrm{Br}_{6} \mathrm{O}_{3}$ : C 40.04, $\mathrm{H} 1.34$; found: $\mathrm{C} 40.09, \mathrm{H} 1.36$.

Second eluate: (syn-1) (92 mg 67\% yield) colorless crystals from $\mathrm{CH}_{2} \mathrm{Cl}_{2} / n$-hexane (1:3), M.p. > $350{ }^{\circ} \mathrm{C}$ (dec.). IR (KBr): 3008, 1723, 1563, 1429, 1351, 1301, 1261, 1172, 1085, 982. $\left.{ }^{1} \mathrm{H} \mathrm{NMR}\left(400 \mathrm{MHz}^{\mathrm{CDCl}}\right)_{3}\right): 7.44(\mathrm{~s}, 6 \mathrm{H})$, 6.08 (s, $6 \mathrm{H}) .{ }^{13} \mathrm{C} \mathrm{NMR}\left(100 \mathrm{MHz}, \mathrm{CDCl}_{3}\right): 146.9,135.5,125.4,122.7,79.8$. Anal. calc. for $\mathrm{C}_{30} \mathrm{H}_{12} \mathrm{Br}_{6} \mathrm{O}_{3}: \mathrm{C} 40.04, \mathrm{H}$ 1.34; found: C 40.07, H 1.33 .

Trinaphthylene (2). In a flame dried 50-ml two-necked round-bottomed flask fitted with argon inlet, titanium(IV) chloride $(0.02 \mathrm{ml}, 0.17 \mathrm{mmol})$ was added to dry THF $(5 \mathrm{ml})$. Lithium aluminumhydride $(2.4 \mathrm{mg}$, $0.06 \mathrm{mmol}$ ) and a solution of triethylamine $(0.03 \mathrm{~mL}, 0.22 \mathrm{mmol})$ in dry THF $(0.5 \mathrm{~mL})$ were added consecutively and the resulting mixture was heated to reflux for $15 \mathrm{~min}$. A solution of anti-1, or a 3:7 mixture of anti-1 and syn-1, (15 mg, $0.02 \mathrm{mmol})$ in dry THF $(2 \mathrm{~mL})$ was added dropwise and the reaction mixture was refluxed for 12 h. The mixture was cooled and portioned between satd. aq. $\mathrm{K}_{2} \mathrm{CO}_{3}(10 \mathrm{~mL})$ and $\mathrm{CHCl}_{3}(3 \times 10 \mathrm{~mL})$. Combined organic extracts were dried over $\mathrm{Na}_{2} \mathrm{SO}_{4}$, concentrated under reduced pressure to afford a solid residue that was purified by column chromatography (silica-gel, $10 \mathrm{~g}$; eluant EtOAc/n-hexane (1:10)) to furnish trinaphthylene 2 (6.2 mg, 98\%) as colorless crystals from $\mathrm{CH}_{2} \mathrm{Cl}_{2} / n$-hexane (1:3), M.p. $>350{ }^{\circ} \mathrm{C}\left(\mathrm{lit} .{ }^{44}>320{ }^{\circ} \mathrm{C}\right)$. ${ }^{1} \mathrm{H}$ NMR $\left.\left(400 \mathrm{MHz}, \mathrm{CDCl}_{3}\right): 9.11(\mathrm{~s}, 6 \mathrm{H}), 8.11-8.07(\mathrm{~m}, 6 \mathrm{H}), 7.59-7.56(\mathrm{~m}, 6 \mathrm{H}) .{ }^{13} \mathrm{C} \mathrm{NMR}\left(100 \mathrm{MHz}^{\mathrm{CDCl}}\right)_{3}\right)$ $133.1,129.2,128.3,126.6,122.9$.

\section{Acknowledgements}

The authors are indebted to Atatürk University (Project no. BAP 2015/91) for financial support.

\section{Supplementary Material}

${ }^{1} \mathrm{H}$ NMR Spectrum of syn-1 anti-1, 2, 4, 5, 6, exo-7 and endo-7, 8, 9; ${ }^{13} \mathrm{C}$ NMR Spectrum of syn-1 and anti-1, 2, 4, 5, 6, 8, 9, Spectrum; and HRMS Spectra 5-6, 8, and 21-23.

\section{References}

1. Fabris, F.; Zonta, C.; Borsato, G.; De Lucchi, O. Acc. Chem. Res. 2011, 44, 416-423. https://doi.org/10.1021/ar100128s

2. Fabris, F.; De Lucchi, O.; Nardini, I.; Crisma, M.; Mazzanti, A.; Mason, S. A.; Cailleau-Lemée, M.-H.; Scaramuzzo, F. A.; Zonta, C. Org. Biomol. Chem. 2012, 10, 2464-2469.

https://doi.org/10.1039/c2ob06774a

3. Bao, X.; Rieth, S.; Stojanović, S.; Hadad, C. M.; Badjić, J. D. Angew. Chem. Int. Ed. 2010, 49, 4816-4819. https://doi.org/10.1002/anie.201000656

4. Rieth, S.; Bao, X.; Wang, B.-Y.; Hadad, C. M.; Badjić, J. D. J. Am. Chem. Soc. 2010, 132, 773-776. https://doi.org/10.1021/ja908436c 
5. Tartaggia, S.; Scarso, A.; Padovan, P.; De Lucchi, O.; Fabris, F. Org. Lett. 2009, 11, 3926-3929. https://doi.org/10.1021/ol901621b

6. Rieth, S.; Wang, B.-Y.; Bao, X.; Badjić, J. D. Org. Lett. 2009, 11, 2495-2498. https://doi.org/10.1021/ol9009392

7. Gardlik, M.; Yan, Z.; Xia, S.; Rieth, S.; Gallucci, J.; Hadad, C. M.; Badjić, J. D. Tetrahedron 2009, 65, 72137219.

https://doi.org/10.1016/j.tet.2008.11.098

8. Wang, B.-Y.; Bao, X.; Yan, .Z.; Maslak, V.; Hadad, C. M.; Badjić, J. D. J. Am. Chem. Soc. 2008, 130, 1512715133.

https://doi.org/10.1021/ja8041977

9. Rieth, S.; Yan, Z.; Xia, S.; Gardlik ,M.; Chow, A.; Fraenkel, G.; Hadad, C. M.; Badjić, J. D. J. Org. Chem. 2008, 73, 5100-5109. https://doi.org/10.1021/j0800748k

10. Scarso, A.; Pellizzaro, L.; De Lucchi, O.; Linden, A.; Fabris, F. Angew. Chem., Int. Ed. 2007, 46, 4972-4975. https://doi.org/10.1002/anie.200701123

11. Fabris, F.; Pellizzaro, L.; Zonta, C.; De Lucchi, O. Eur. J. Org. Chem. 2007, 283-291. https://doi.org/10.1002/ejoc.200600673

12. Yan, Z.; Xia, S.; Gardlik, M.; Seo, W.; Maslak, V.; Gallucci, J.; Hadad, C. M.; Badjić, J. D. Org. Lett. 2007, 9, 2301-2304. https://doi.org/10.1021/ol0705595

13. Maslak, V.; Yan, Z.; Xia, S.; Gallucci, J.; Hadad, C. M.; Badjić, J. D. J. Am. Chem. Soc. 2006, 128, 5887-5894. https://doi.org/10.1021/ja060534l

14. Zonta, C.; Cossu, S.; De Lucchi, O. Eur. J. Org. Chem. 2000, 1965-1971. https://doi.org/10.1002/(SICI)1099-0690(200005)2000:10<1965::AID-EJOC1965>3.0.CO;2-C

15. Venugopalan, P.; Burgi, H.-B.; Frank, N. L.; Baldrige, K. K.; Siegel, J. S. Tetrahedron Lett. 1995, 36, 24192422. https://doi.org/10.1016/0040-4039(95)00318-7

16. Gandeepan, P.; Rajamalli, P.; Cheng, C.-H. Angew. Chem. Int. Ed. 2016, 55, 4308-4311. https://doi.org/10.1002/anie.201512018

17. Link, A.; Fischer, C.; Sparr, C. Angew. Chem. Int. Ed. 2015, 54, 12163-12166. https://doi.org/10.1002/anie.201505414

18. Akita, R.; Kawanishi, K.; Hamura, T. Org. Lett. 2015, 17, 3094-3097. https://doi.org/10.1021/acs.orglett.5b01364

19. Haneda, H.; Eda, S.; Aratani, M.; Hamura, T. Org. Lett. 2014, 16, 286-289. https://doi.org/10.1021/ol4032792

20. Luo, R.; Liao, J.; Xie, L.; Tang, W.; Chan, A. S. C. Chem. Commun. 2013, 49, 9959-9961. https://doi.org/10.1039/c3cc46009f

21. Standera, M.;Häfliger, R.;Gershoni-Poranne, R.; Stanger, A.; Jeschke, van Beek, J. D.; Bertschi, L.; Schlueter, A. D. Chem. Eur. J. 2011, 17, 12163-12174.

https://doi.org/10.1002/chem.201100443

22. Davoust, M.; Kitching, J. A.; Fleming, M. J.; Lautens, M. Chem. Eur. J. 2010, 16, 50-54. https://doi.org/10.1002/chem.200902694

23. Anthony, I. J.; Wege, D. Austr. J. Chem. 1996, 49, 1263-1272. https://doi.org/10.1071/CH9961263 
24. Hart, H.; Lai, C.; Nwokogu, G. C.; Shamouilian, S. Tetrahedron 1987, 43, 5203-5224. https://doi.org/10.1016/S0040-4020(01)87696-1

25. Standera, M.; Haefliger, R.; Gershoni-Poranne, R.; Stanger, A.; Jeschke, G.; Hart, H.; Bashir-Hashemi, A.; Luo, J.; Meador, M. A. Tetrahedron 1986, 42,1641-1654. https://doi.org/10.1016/S0040-4020(01)87581-5

26. Altundas, A.; Dastan, A.; McKee, M. M.; Balci, M. Tetrahedron, 2000, 56, 6115-6120. https://doi.org/10.1016/S0040-4020(00)00561-5

27. Giorgio, E.; Rosini, C.; Fabris, F.; Fregonese, E.; Toniolo, U.; De Lucchi, O. Chirality 2009, 21, S86-S97. https://doi.org/10.1002/chir.20780

28. Borsato, G.; Brussolo, S.; Crisma, M.; De Lucchi, O.; Lucchini, V.; Zambon, A. Synlett, 2005, 1125-1128. https://doi.org/10.1055/s-2005-865215

29. Fabris, F.; Zambrini, L.; Rosso, E.; De Lucchi, O. Eur. J. Org. Chem. 2004, 3313-3322. https://doi.org/10.1002/ejoc.200400120

30. Dastan, A.; Uzundumlu, E.; Balci, M.; Fabris, F.; De Lucchi, O. Eur. J. Org. Chem. 2004, 183-192. https://doi.org/10.1002/ejoc.200300478

31. Sakurai, H.; Daiko, T.; Hirao, T. Science, 2003, 301, 1878. https://doi.org/10.1126/science.1088290

32. Fabris, F.; Bellotto, L.; De Lucchi, O. Tetrahedron Lett. 2003, 44, 1211-1213. https://doi.org/10.1016/S0040-4039(02)02789-2

33. Borsato, G.; De Lucchi, O.; Fabris, F.; Lucchini, V.; Pasqualotti, M.; Zambon, A. Tetrahedron Lett. 2003, 44, 561-563.

https://doi.org/10.1016/S0040-4039(02)02533-9

34. Bolzan, A.; Bortoluzzi, M.; Borsato, G.; Fabbro, C.; Dastan, A.; De Lucchi, O.; Fabris, F. Helv. Chim. Acta 2015, 98, 1067-1074.

https://doi.org/10.1002/hlca.201500018

35. Dastan, A.; Fabris, F.; De Lucchi, O.; Guney, M.; Balci, M. Helv. Chim. Acta 2003, 86, 3411-3416. https://doi.org/10.1002/hlca.200390285

36. Borsato, G.; De Lucchi, O.; Fabris, F.; Groppo, L.; Lucchini, V.; Zambon, A. J. Org. Chem. 2002, 67, 78947897. https://doi.org/10.1021/jo020396s

37. Yan, Z.; McCracken, T.; Xia, S.; Maslak, V.; Gallucci, J.; Hadad, C. M.; Badjić, J. D. J. Org. Chem. 2008, 73, 355-363.

https://doi.org/10.1021/jo701538g

38. De Lucchi, O.; Dastan, A.; Altundas, A.; Fabris, F.; Balci, M. Helv. Chim. Acta 2004, 87, 2364-2367. https://doi.org/10.1002/hlca.200490213

39. Engelhart, J. U.; Tverskoy, O.; Bunz, U. H. F. J. Am. Chem. Soc. 2014, 136, 15166-15169. https://doi.org/10.1021/ja509723q

40. Haneda, H.; Eda, S.; Aratani, M.; Hamura, T. Org. Lett. 2014, 16, 286-289. https://doi.org/10.1021/ol4032792

41. Dai, G.; Chang, J.; Zhang, W.; Bai, S.; Huang, K. W.; Xu, J.; Chi, C. Chem. Commun. 2015, 51, 503-506. https://doi.org/10.1039/C4CC07630C

42. Niu, W. X.; Yang, E. Q.; Shi, Z. F.; Cao, X. P.; Kuck, D. J. Org. Chem. 2012, 77, 1422-1434. https://doi.org/10.1021/jo2022668 
43. Akin, E. T.; Erdogan, M.; Dastan, A.; Saracoglu, N. Tetrahedron, 2017, 73, 5537-5546. https://doi.org/10.1016/i.tet.2017.07.058

44. Garcia-Lopez, J.-A.; Greaney, M. F. Org. Lett. 2014, 16, 2338-2341. https://doi.org/10.1021/ol5006246

45. Brockmann, H.; Greve, H.; Waldmuller, W.; Chem. Ber. 1971, 104, 1436-1454. https://doi.org/10.1002/cber.19711040512

46. Hausigk, D. Chem. Ber. 1970, 103, 659-662. https://doi.org/10.1002/cber.19701030302

47. Bell, F.; Hunter, W. H. J. Chem. Soc. 1950, 2903-2904.

48. Pummerer, R.; Pfaff, A.; Riegelbauer, G.; Rosenhauer, E. Chem. Ber. 1939, 72, 1623. https://doi.org/10.1002/cber.19390720829

49. Pummerer, R.; Luttringhaus, A.; Fick, R.; Pfaff, A.; Riegelbauer, G.; Rosenhauer, E. Chem. Ber. 1938, 71, 2569-2572.

https://doi.org/10.1002/cber.19380711224

50. Rosenbauer, E.; Braun, F.; Pummerer, R.; Riegelbauer, G. Chem. Ber. 1937, 70, 2281-2287. https://doi.org/10.1002/cber.19370701117 